Running head: GENDER \& MOTIVATIONS FOR CASINO GAMBLING

\title{
Inter- and Intra-Gender Similarities and Differences in Motivations for Casino Gambling
}

Gordon J. Walker, Thomas D. Hinch, \& A. J. Weighill

Faculty of Physical Education and Recreation

University of Alberta

This manuscript has not been published previously and is being submitted for exclusive publication consideration in Leisure Sciences

This research was supported by a grant from the Alberta Gaming Research Institute. The authors would like to thank the University of Alberta Population Research Lab staff for their assistance collecting the data. Correspondence concerning this article should be addressed to Gordon J. Walker, E-424 Van Vliet Centre, Faculty of Physical Education and Recreation, University of Alberta, Edmonton, Alberta, Canada, T6G 2H9. E-mail: gordon.walker@ualberta.ca 


\begin{abstract}
The two objectives of this study were to examine if motivations for casino gambling vary by gender and, based on motivations for casino gambling, to ascertain different types of male and female gamblers. To accomplish these objectives, five casino motivation scales were developed. Nine hundred male and female casino patrons living in two major Canadian metropolitan areas completed a telephone questionnaire. Male study participants rated risk-taking/gambling as a rush and learning/cognitive self-classification as being more important than did female participants. Two types of male casino gamblers existed: men who gave primacy to risktaking/gambling as a rush and emotional self-classification, and men who gave primacy to communing. Three types of female casino gamblers existed: women who gave primacy to emotional self-classification and escaping everyday problems, women who gave primacy to communing and emotional self-classification, and women who gave primacy to communing alone. Gender theory was used to explain these findings, and study limitations and future research recommendations were also discussed.
\end{abstract}

Key words: casino gambling, cluster analysis, gender, masculinity, motivation. 


\section{Inter- and Intra-Gender Similarities and Differences in Motivations for Casino Gambling}

Gambling generally, and casino gambling specifically, have become popular and economically important leisure activities. For example, in the only national study of gambling behavior conducted in Canada, Azmier (2000) found that 72\% of respondents reported having gambled in the past 12 months. Although playing the lottery was the most popular gambling activity (50\%), in-province casino gambling was ranked fourth (17\%), out-of-province casino gambling was ninth (6\%), and out-of-country casino gambling was tenth (5\%). Azmier (2001) noted in a follow-up study that 1999/2000 net revenue from casinos actually exceeded the revenue of lottery products (\$1,901 million vs. \$1,890 million Canadian, respectively). Further, while casino gambling accounted for only 1\% of Canada's gross gambling profit in 1992, it accounted for $29 \%$ in 2000. In comparison, Welte, Barnes, Wieczorek, Tidwell, and Parker (2002) found that $82 \%$ of Americans reported having gambled in the past 12 months with the most popular gambling activities being the lottery (66\%) followed by raffles, office pools, and charitable gambling (48\%), and then casino gambling (27\%). While casino gambling was participated in less often than the other two activities, respondents reported that the average absolute value of their last win or loss was \$11 U.S. for lotteries, \$23 U.S. for raffles, office pools, and charitable gambling, and \$143 U.S. for casino gambling.

In spite of casino gambling's growing popularity and substantial economic impact, relatively little research has been conducted on this activity in recreation and leisure studies. ${ }^{1}$ Cotte's (1997) qualitative study is one of the few exceptions. Based on observations and conversations, Cotte developed a three dimension typology consisting of eight motivations: learning/evaluating, gambling as "a rush," self-definition, risk-taking, cognitive self- 
classification, emotional self-classification, competing, and communing. Unfortunately, one of the limitations of Cotte's study is that she did not address how these motivations may vary due to gender. This oversight is not unusual as Hing and Breen (2001) and others (Bruce \& Johnson, 1994; Trevorrow \& Moore, 1999; Volberg, 2003) have contended that limited research exists on female motivations for gambling. Furthermore, differences in the social and economic realities of men and women also create within gender group similarities and differences (Henderson, 1996; Henderson, Bialeschki, Shaw, \& Freysinger, 1989; Shaw, 1999). Thus, research that examines intra-gender variation is also needed. Finally, this type of research expands not only the existing body of literature on leisure experiences that is grounded in theories of gender development and that uses gender as an "explanatory variable rather than a descriptive variable" (Henderson, 1990, p. 228), but also addresses the paucity of research "on the gendered nature of men's leisure" (Henderson \& Shaw, 2003, p. 1).

The two objectives of this study were to examine if motivations for casino gambling vary by gender and, based on motivations for casino gambling, to ascertain different types of male and female gamblers. The review of the literature is divided into three sections: the concept of gender, motivations for casino gambling, and the intersection between gender and casino gambling motivations.

\section{Literature Review}

\section{Gender}

The concept of gender is both complex and contested. For example, biological differences define one's sex, and less concrete socially constructed differences dictate one's gender. While most notions of gender are based on the polarization of feminine and masculine traits, gender differences more likely exist along a continuum (Mackie, 1991). The process 
through which one develops an understanding of their gender role is contested from several theoretical perspectives (e.g., socialization, psychoanalytic conflict, and identity formation). These theories attempt to explain how children and adults develop and select their own gendered identity (Bem, 1993). However, for this study it is more important to understand the implications of living in a society that "construct(s) conventionally gendered women and men by situating people in a culture whose discourses and social practices are organized around the lenses of androcentrism and gender polarization" (Bem, p. 142). The remainder of this section will focus on the ways in which androcentrism and gender polarization impact males and females in North American society.

Bem (1993) argued that androcentrism functions in two ways: first, situating males and females into different and unequal positions in the social structure, and second, communicating the notion that "males are the privileged sex and the male perspective is the privileged perspective" (p. 144). Bem also argued that androcentric notions toward women focus on domestic and reproductive functions, sexuality as related to their ability to attract and satisfy men, and to women being an "inferior departure from the male standard" (p. 144). As a result of this androcentric social structure, men have enjoyed greater social prestige as well as economic and political power (Mackie, 1991).

The imbalance of power between men and women permeates throughout all aspects of society with the impacts being felt on both sides of the gender continuum. For instance, Marin (1995) suggested that single adult males comprise the majority of the homeless population due in part to both the gendered emotional socialization of men as well as men's traditional participation in transient and marginal jobs (e.g., railway workers, loggers, miners, etc.). Similarly, women head the vast majority of single parent households and, when compared to their male 
counterparts they are found to be younger, less educated, and more likely to be raising younger children. For these women the economic reality of single parenthood is generally one of great hardship with employment opportunities often being restricted to "low-wage occupations or income from government transfer payment programs" (Oderkirk \& Lochhead, 1995, p. 398).

Other non-economic aspects of life are also affected by the androcentric nature of North American society. For example, women have faced greater constraints to their participation in leisure activities and to their experience of leisure (Henderson et al., 1989), while males have had to constantly prove their masculinity (Beneke, 1997) in all areas of life including their leisure pursuits. Beneke argued that, "the whole domain of male sports constitutes an occasion for proving manhood" (p. 40), where the ability to withstand physical pain and psychological pressure is key. He further suggested that, "the sheer psychological pressure exerted by the importance of winning or performing well enables one to prove manhood" (p. 40). The problematic nature of this "compulsive masculinity" is that men who are unable to attain the same physical and psychological standard are demeaned and the idea that being less than male (i.e., female) is undesirable is reinforced.

This discussion of gender is in no way exhaustive and does not do justice to the endless ways in which the gendered nature of North American society influences all aspects of daily life. However, the existence of a variety of impacts of androcentrism and socially constructed meanings of what it is to be a man or a woman has been illustrated. How these impacts and meanings may differentially affect men and women's motivations for casino gambling will be discussed more fully following a review of the research on casino gambling motivations. 


\section{Motivations for Casino Gambling}

Although recreation and leisure-based researchers have seldom analyzed motivations for gambling and casino gambling, other social science researchers have done so to a modest degree. Cotte (1997) identified various research studies in sociology, psychology, and psychoanalytic theory. Four general categories for why people gamble emerged from Cotte's research: (a) economic motives, (b) symbolic motives, (c) hedonic motives, and (d) experiential consumption motives. Following Cotte's example, we briefly discuss the first three categories but attend most fully to the experiential consumption category.

Economic, symbolic, and hedonic motives.

The desire to make money is often put forward as a "common sense" reason for gambling (Cotte, 1997). Although some support for this proposition exists (Neighbors, Lostutter, Cronce, \& Larimer, 2002), a number of researchers (Geertz, 1973; Walker, 1992) believe that making money may, in fact, only be an incidental reason for why people gamble. Most casino gamblers recognize that the odds of winning are small (Cotte) while casinos intentionally de-emphasize the monetary aspect by ensuring that cash quickly disappears (into drop boxes, for example) and is replaced by playing pieces such as poker chips (Abt \& Smith, 1982). This economic argument has also demonstrated little value in terms of charitable gambling (i.e., participating for the express purpose of funding a charity) at casinos as gamblers almost never report this reason for their gambling (Azmier, 2000).

Research on symbolic motives for casino gambling is much less common in the literature. Abt, Smith, and McGurrin's (1985) examination of casino and horse race track gambling appeared to be both the most recent and the most relevant of this latter type of research. These researchers contend that: "gambling can be viewed as occurring within social boundaries that 
create a social organization and symbolic meaning system within the race track or casino" (p. 64). According to Abt et al., this "recreational world" may become more fulfilling than the real world the person inhabits, particularly if he or she seeks escape from everyday problems such as unpaid bills or discontented babies. As with any social world, norms exist for how one should behave, including acting in a way that does not threaten the group's cohesiveness or that does not interrupt the gambling action, especially when one loses. Abt et al. discussed this process in terms of "integration" (Goffman, 1961) that occurs when fellow gamblers help the loser "cool out" (e.g., by saying "Those dice have been cold all night"), or when the loser cools him or herself out (vs. "flooding out" by either cursing or bursting out laughing). Abt et al. add: It is apparent that some players are better than others at maintaining their roles without incident and without flooding out, and it is this type of controlled player who is looked at with admiration by other gamblers: "They're always cool. Who would know they just lost thousands?" Such a gambler is the epitome of the ideal player in terms of system integration. (p. 73)

Hedonic motives, in contrast, are more closely associated with both classic and contemporary leisure research. For example, Huizinga (1955) stated that games of chance represent one type of play, although he later added that more skill-based games of chance have shifted toward "serious and over-seriousness" (p. 198) with the loss of the play-element. These non-playful gambling activities are still perceived as being fun and enjoyable, although often in a "morally marginal" manner similar to drug use and commercialized sex (Kraus, 2001).

Hedonism not only involves the pursuit of pleasure but also the avoidance of pain (Chaplin, 1985; Mannell \& Kleiber, 1997). This avoidance is often seen in terms of escape from everyday problems, as well as escape from the self. According to Baumeister (1991), people seek to escape 
from the self in order to avoid thinking bad thoughts about oneself or to find "temporary relief from the stressful burden of maintaining an inflated image of oneself" (p. 21). Baumeister explained the process of escaping the self as:

meaning links your physical self with many other people, places, times, and events. To escape from yourself is to lose awareness of all those connections.... [During escape] your awareness of self shrinks to the immediate time and place (the room you are in, here and now) and to the short-term movements and sensations of your body. (p. 18)

Baumeister briefly mentions that some leisure activities, such as playing games, could provide a means for escape. Games of chance, especially those found in timeless places such as casinos (which generally lack temporal reference points such as clocks or windows), could be one such type of game.

In conclusion, while the economic motive for casino gambling may be largely incidental, both the hedonic and symbolic motives do appear to provide some insight into why people gamble. Further discussion of these two motivation categories in the context of experiential consumption follows.

\section{Experiential consumption motives.}

Over the past decade or so, consumer researchers have studied the experiential aspects of a variety of leisure activities including skydiving (Celsi, Rose, \& Leigh, 1993), river rafting (Arnould \& Price, 1993), professional baseball spectatorship (Holt, 1995), visiting a flea market (Sherry, 1990), and casino gambling (Cotte, 1997). According to Cotte, many studies found that common concepts underlay the experiential consumption of these different leisure activities. For example, skydivers (Celsi et al., 1993) and river rafters (Arnould \& Price, 1993) reported experiencing and being motivated by intense feelings of interpersonal interaction. Holt (1995) 
developed a matrix of baseball spectators' actions based on a person's focus (i.e., the activity or the interpersonal situation) and purpose (i.e., autotelic, with consumption being an end in itself, or instrumental, with consumption being a means to an end). This matrix became the basis for Cotte's (1997) typology of casino gambling motives, albeit only after she had: (a) identified emergent themes from partial "observations and overhead conversations, as well as direct conversations with gambling informants" at one casino (p. 390); and (b) integrated Sherry's (1990) work on the distinction between rational/utilitarian and emotional/hedonic consumption experiences into Holt's framework. The eight motives Cotte identified and the dimensional concepts underlying each are reported in Table 1.

Although Cotte's (1997) learning/evaluating, gambling as a rush, risk-taking, competing, and communing motives are relatively self-explanatory, her other three motives require further elaboration. Specifically, self-definition refers to an individual being motivated to identify her or himself as a specific type of person (e.g., as a casino pro). In contrast, cognitive selfclassification refers to an individual being motivated to establish a specific type of reputation with others (e.g., as a proficient gambler). Finally, emotional self-classification refers to an individual being motivated to represent him or herself in a specific emotional manner (e.g., as a stoic winner or loser).

In conclusion, Cotte's (1997) typology appeared to provide an excellent starting point for examining casino gambling motives. Cotte suggested in her paper that, while the ethnographic approach she used was appropriate for her initial research questions, future research should consider using other methodologies including rating scales based on the motives she identified. 


\section{Gender and Motivations for Gambling and Casino Gambling}

One advantage of a follow-up study to Cotte's (1997) work would be the ability to address the paucity of research on gender and motivations for gambling (Bruce \& Johnson, 1994; Hing \& Breen, 2001; Trevorrow \& Moore, 1999; Volberg, 2003). Many prior studies have focused on male gamblers' desire to take risks and female gamblers' desire to escape. Studies by Hudgens and Fatkin (1985) and Bruce and Johnson (1994) have found that, in general, males are less cautious risk takers than females. Although some research suggests a biological basis for why this difference exists (e.g., sensation seeking; Zuckerman, 1979), some gender scholars have proposed alternative explanations. Typically, these alternatives are based on the concepts of gender roles and socialization and argue that, "what it means to be a female or a male are significantly influenced by cultural and societal values" (Etaugh \& Bridges, 2001, p. 22).

Kimmel (1996) contended that masculinity must constantly be proven and described war as one way this is accomplished. Lois (2001) believed that more readily available avenues also existed, such as participating in risky leisure activities, or "edgework" (Lyng, 1990). Beneke (1997) noted, however, that it is not only the type of activity that proves a man's masculinity but also how its consequences are handled emotionally. For example, Lois (2001) described how male search and rescue workers, in contrast with female workers, would usually release their emotions in a slow, controlled manner regardless of their success or failure. One explanation for this behavior was that the norm of masculine emotional stoicism (Connell, 1987; Kimmel, 1996) was "strongly entrenched and intricately connected to the edgework subculture" (p. 403). This suggestion could mean that male casino gamblers may also be motivated not to display their emotions or what Cotte (1997) called emotional self-classification. Finally, proving one's masculinity through edgework and emotional control while in the presence of an audience may 
parallel male casino gamblers motivation to establish their reputation, or what Cotte (1997) called cognitive self-classification. Thus, risk-taking, gambling as a rush, emotional selfclassification, and cognitive self-classification may be more important motivations for male casino gamblers than for female casino gamblers.

Although little research exists on female motivations for gambling, "what little has been conducted tends to suggest that women gamble to escape from boredom and to gain time out from family responsibilities" (Hing \& Breen, 2001, p. 65). These findings were similar to those found by leisure researchers who argued that leisure is a potential site for the resistance of traditional gendered roles such as caregiver and homemaker (Freysinger \& Flannery, 1992; Shaw, 2001; Weighill, 2001). In addition to the previous escape motivations (e.g., Brown \& Coventry, 1997; Lesieur, 1993), trying to escape from depression is also a commonly cited reason for why women gamble (Hing \& Breen, 2001) and "problem" gamble (Getty, Watson, \& Frisch, 2000). Casino gambling (like drugs or alcohol) may therefore be a way to escape the self (Baumeister, 1990, 1991) in order to cope with depression. Thus, escaping everyday problems and escaping the self may be more important motivations for female casino gamblers than for male casino gamblers.

Although ideas can be proposed how certain motivations will differ between male and female casino gamblers, variations in other motivations are not as clear. For example, while some evidence of the importance of communing exists among female bingo players (Dixley, 1987), it is unclear if there is any variation due to gender. Furthermore, while we agree with Shaw (1999) and others (Henderson, 1996) that intra-gender as well as inter-gender variation in leisure must be examined, the general lack of research on other motivations for casino gambling precludes us from making any other propositions. Therefore, the focus of our study was to 
explore intra-gender and inter-gender variations in casino gambling motivations. By doing so, the current study could add to the existing body of literature on leisure experiences that is grounded in theories of gender development and that uses gender as an "explanatory variable rather than a descriptive variable" (Henderson, 1990, p. 228).

\section{Method}

Sample, Study Instrument, and Measurement Items

A random sample of telephones numbers for two major Western Canadian city metropolitan areas was generated. ${ }^{2}$ The initial screening questions: (a) selected either a male or female potential respondent, (b) established whether she or he had gambled in a casino in the past 12 months (with the respondent determining what the term "gambled" meant), and (c) if so, used open-ended questions to ascertain how frequently to a "local" casino (i.e. less than 80 kilometres), a "distant" casino (i.e., greater than 80 kilometres), or both. Data were collected from 900 people (51\% female; 49\% male) with 400 of these individuals indicating that they had visited a distant casino in the past year. In order to obtain this sample 19,002 telephone numbers were called with many of these numbers subsequently being excluded for various reasons including business/fax/children's number $(4,082)$, not in service $(2,877)$, answering machine (1,473), no answer (1,189), line trouble (677), busy (461), and other (692). Finally, 4,839 people reported that they had not gambled at a casino in the past 12 months while 1,812 people refused to participate.

The study instrument consisted of a CATI (Computer-Assisted Telephone Interviewing) questionnaire that included the previously described screening items as well as items on travel behavior for those who had visited a distant casino, attachment to the last casino visited, 
motivations for casino gambling, and socio-demographic characteristics. On average, participants took 20 minutes to complete the telephone survey.

Based on descriptions of seven of Cotte's (1997) casino gambling motivations (i.e., risktaking, competing, communing, learning/evaluating, gambling as a rush, cognitive selfclassification, emotional self-classification), as well as descriptions of two other motivations (i.e., escaping the self, escaping everyday problems) identified in the literature review, potential items were either selected from analogous scales (e.g., Recreation Experience Preference items; Manfredo, Driver, \& Tarrant, 1996) or were developed specifically for this study. ${ }^{3}$

\section{Data Analysis}

Five types of data analysis were conducted to test the research objectives. First, exploratory factor analysis using promax rotation (Fabrigar, Wegener, MacCallum, \& Strahan, 1999) was performed to examine the casino gambling motivation scales' structure. According to Comrey and Lee (1992), a sample size of 900 falls within the very good to excellent range. Comrey and Lee also stated that an item which loads $\geq|.55|$ (30\% overlapping variance) on a factor should be rated as "good" while an item that loads $\leq|.32|$ (10\% overlapping variance) on a factor should be rated as "poor." This criterion was used to establish that an item was an adequate measure.

Second, after deleting individuals whose responses exhibited total invariance (i.e., all scale means exactly equal), a multivariate analysis of variance (MANOVA) was conducted on the motivation scales using gender as the independent variable. Because the MANOVA was significant, a series of analysis of variance (ANOVAs) were also performed.

Third, the sample was randomly split into a study group and a validation group. For both groups, within-case standardization (i.e., for each participant, his or her average motivation score 
was subtracted from his or her score on each motivation scale) was calculated (Hair \& Black, 2000). Cluster analysis (using the SAS FASTCLUS program) was performed on the study group to examine potential types of male and female gamblers. The number of clusters was determined using the Pseudo-F method, a stopping technique that has demonstrated better-than-average results in Monte Carlo evaluations (Milligan \& Cooper, 1985). T-tests were then conducted to determine which motivations differed significantly from $0.00(p<.01$ being used to control for Type II error), while visual examination was employed to ascertain which motivations were of primary importance for each cluster.

Fourth, validation of the cluster solution was determined two ways. First, with the study group we established how the clusters exhibited anticipated similarities and differences on the variable mode of experience (Williams, Patterson, Roggenbuck, \& Watson, 1992) that had not been used to form the clusters initially (i.e., criterion validity). Second, cluster analysis was performed on the group of participants who had been randomly excluded earlier and these results were compared with the study group.

Fifth, chi-square tests were conducted on the study group using socio-demographic and frequency level characteristics to examine within-gender variation between the clusters. Participant Socio-Demographic Information

Participant's age, education, employment status, and frequency of visiting a casino were ascertained. The average age of male participants was 39 years versus 44 years of age for female participants. Approximately 27\% of male participants had completed high school, 19\% had completed a Bachelors degree, $12 \%$ had completed community college, and 13\% had some university. Approximately 28\% of female participants had completed high school, 21\% had completed a Bachelors degree, 16\% had completed community college, and 11\% had some 
university. Male participants were more likely to report being employed full-time (73\%) than were female participants (55\%), while females were more likely to indicate that they were either retired (19\% vs. $7 \%$ ) or homemakers (9\% vs. $0 \%) .{ }^{4}$ Male participants reported visiting casinos more frequently than female participants during the past year (8.7 vs. 6.5 visits, respectively). ${ }^{5}$

\section{Results}

\section{Exploratory Factor Analysis}

Table 2 reports the results of the exploratory factor analysis that used promax rotation for the 14 motivation items that met the factor loading criteria. The decision to use a five-factor solution was based on a visual examination of the scree plot rather than the commonly used Kaiser criterion (i.e., eigenvalues $\geq 1.0$ ) since a number of studies (see Fabrigar et al., 1999) have recommended the use of scree plots.

The first factor measured risk taking/gambling as a rush. Four motivation items from two scales loaded on this factor: "To take risks" and "To take chances" (the risk-taking scale) and "To have thrills" and "To feel exhilaration" (the gambling as a rush scale). This finding was not surprising since both of these motivations have the activity as their focus and are emotional/hedonic. Although Cotte contended that risk-taking involves instrumental actions while gambling as a rush involves autotelic actions, these two motivations could also be interpreted in terms of cause (i.e., taking a risk) and effect (i.e., experiencing a rush). The results of the data analysis suggested that this factor is both unidimensional (since all four items loaded on the first factor $\geq|.55|$ and on the other four factors $\leq|.32|$ ) and reliable (standardized Cronbach coefficient alpha $=.85)$.

The second factor measured learning/cognitive self-classification. Four motivation items that represented three scales loaded on this factor: "To be seen by others as a smart gambler" and 
"To be seen by others as a skilled player" (the cognitive self-classification scale); "To develop your skills and abilities" (the learning and evaluating scale); and "To keep a 'poker face' when you're gambling" (the emotional self-classification scale). This result may be due to: (a) study participants believing that being able to keep a "poker face" is less an aspect of emotional selfclassification and more a skill or ability (cf. Walker, 1992), and (b) some gamblers may want to demonstrate their proficiency in order to cognitively classify themselves as being part of the casino world (Cotte, 1997). The results of the data analysis suggested that this factor is also both unidimensional and reliable (standardized Cronbach coefficient alpha $=.74$ ).

The third factor measured escaping everyday problems. Two motivation items loaded on this factor: "To avoid everyday problems for awhile" and "To get away from the usual demands of life". This factor is also unidimensional and reliable (standardized Cronbach coefficient alpha $=.81)$.

The fourth factor measured communing. Two motivation items also loaded on this factor: "To be with members of your group" and "To do things with your companions". This factor is also unidimensional and reliable (standardized Cronbach coefficient alpha $=.76$ ).

The fifth factor measured emotional self-classification. Two motivation items also loaded on this factor: "To be in control whether you win or lose" and "To just be yourself". The scale's standardized Cronbach coefficient alpha of .49 was somewhat low even for a two-item scale. However, the emotional self-classification scale was included in subsequent data analyses based on Tabachnick and Fidell's (1996) argument that sometimes, "the last few factors represent the most interesting and unexpected findings in a research area" (p. 674). 


\section{Multivariate Analysis of Variance and Follow-up Analysis of Variance}

A MANOVA conducted on the five casino gambling motivation scales using gender was significant [Wilk's $\Lambda=.89, F(5,871)=20.85, p<.0001]$ which suggested that male and female participants differed overall in regard to their motivations for casino gambling. ${ }^{6}$ According to Weinfurt (1995), the $\eta^{2}$ for this analysis indicates a medium effect size. Table 3 reports the results of the ANOVAs that were subsequently performed on each motivation by gender. Two of the motivations were significantly more important for male participants than for female participants: risk-taking/gambling as a rush and learning/cognitive self-classification. Based on Cohen's (1977; 1992) recommendations, the learning/cognitive self-classification motivation's $d$ is indicative of a small effect size while the risk-taking/gambling as a rush motivation's $d$ is indicative of a medium effect size.

\section{Cluster Analysis}

Six separate cluster analysis were performed on the study group using gender and the number of clusters requested. Examination of the Pseudo- $F$ Statistic results indicated that a twocluster solution was optimal for males (Pseudo- $F=96.93$ ) while a three-cluster solution was optimal for females (Pseudo- $F=71.65$ ). Fewer males were found (Table 4) in the first cluster compared with the second cluster (44\% and 56\%, respectively), while the number of females in the first cluster was less than the second and third clusters (27\%,36\%, and 38\%, respectively). ${ }^{7}$

Each cluster's primary gambling motivations were ascertained after t-tests determined which motivations' means differed significantly from 0.00 . For males in the study group, risktaking/gambling as a rush $(M=0.41)$ and emotional self-classification $(M=0.20)$ were the most important motivations for the first cluster. Communing $(M=1.30)$ and, to a lesser extent, emotional self-classification $(M=0.42)$ were most important for the second cluster. For females 
in the study group, emotional self-classification $(M=0.75)$ and, to a lesser degree, escaping everyday problems $(M=0.30)$ were the most important motivations found in the first cluster. Communing $(M=1.29)$ and emotional self-classification $(M=1.07)$ were most important for the second cluster while communing $(M=0.88)$ was the sole motivation for the third cluster. Validation of the Cluster Solution

Validation of the cluster solution was determined two ways. First, with the study group we established how the clusters exhibited anticipated similarities and differences on a variable that had not been used to form the clusters initially. Specifically, participants indicated which of Williams' et al. (1992) three experiences modes (i.e., the activity, the place, or their companions) was most important during their last casino visit. A chi-square test with the study group's two male clusters was significant $\left[\chi^{2}(2, N=213)=40.34, p<.0001 ; V=.44\right]$. Males in the first cluster emphasized the motivations of risk-taking/gambling as a rush and emotional selfclassification and were more likely than expected to report that the activity was the most important aspect of their last casino visit. In contrast, males in the second cluster emphasized the communing motivation and emotional self-classification and were more likely than expected to report that their companions were the most important aspect of their last casino visit. A chisquare test with the study group's three female clusters was also significant $\left[\chi^{2}(4, N=200)=\right.$ 16.63, $p=.0023 ; V=.20]$. Females in the first cluster emphasized the motivations of emotional self-classification and escaping everyday problems and were more likely than expected to report that the place and the activity were the most important aspects of their last casino visit. Similarly, females in the second cluster emphasized the motivations of communing and emotional selfclassification and were more likely than expected to report that companions were the most important aspect of their last casino visit. Females in the third cluster emphasized the 
communing motivation and did not appear to focus on any one mode. These results support the criterion validity of the cluster solution.

Second, validation of the cluster solution was determined by performing cluster analysis on the group of participants who had been randomly excluded earlier and comparing these results with those of the study group's. Specifically, six separate cluster analysis were performed on the validation group using gender and the number of clusters requested. Examination of the PseudoF method results indicated that a three-cluster solution was optimal for males (Pseudo- $F=72.17$ ) while a two-cluster solution was optimal for females (Pseudo- $F=96.73$ ). More males were found (Table 5) in the first cluster (39\%) compared with the second and third clusters (32\% and $29 \%$, respectively), while the number of females in the first cluster was less than the second cluster (46\% vs. 54\%, respectively).

Each cluster's primary gambling motivations were ascertained after t-tests determined which motivation's means differed significantly from 0.00 . Males in the first cluster of the validation group reported communing $(M=1.29)$ was the most important motivation. Emotional self-classification $(M=1.09)$ and communing $(M=0.66)$ were the most important motivations for the second cluster. Risk-taking/gambling as a rush $(M=0.47)$ and escaping everyday problems $(M=0.25)$ were the most important motivations for the third cluster. For females in the validation group, the most important motivations were emotional self-classification $(M=0.27)$ and escaping everyday problems $(M=0.21)$ for the first cluster, and communing $(M=1.33)$ and emotional self-classification $(M=0.54)$ for the second cluster.

What is most evident about the results is that for males, two clusters emerged in the study group while three emerged in the validation group. Correspondingly, three clusters emerged in the female study group while only two emerged in the validation group. Although this finding 
was unexpected, some important similarities were found between the two groups' motivational structures. For example, one cluster of females in the study group and one cluster of females in the validation group reported that communing and emotional self-classification motivated them to gamble in casinos, while another cluster indicated that emotional self-classification and escaping everyday problems motivated them to gamble. Similarly, one cluster of males in the study group and one cluster of males in the validation group reported that risk-taking/gambling as a rush motivated them to gamble in casinos, while another cluster of males reported that communing and emotional self-classification motivated them to gamble (although the order of these two motivations differed between the two clusters). The additional cluster of females in the study group and the additional cluster of males in the validation group both reported that communing alone was what motivated them to gamble in casinos. These results also support the cluster solution, albeit not as strongly as the first part of the validation process.

\section{Within-Gender Variation Between the Clusters}

Chi-square tests were conducted on the study group using socio-demographic and frequency level characteristics to examine intra-gender variation between the clusters. Results of these tests indicated that for males in the study group, the two clusters did not differ significantly $(p>.05)$ in terms of their age, education level, or current job status (e.g., employed full-time, employed part-time, etc.). Similarly, females in the study group also did not differ significantly $(p>.05)$ on any of these socio-demographic variables. Some significant differences were found when frequency level was examined. For example, a chi-square test conducted on the males in the study group was significant $\left[\chi^{2}(2, N=217)=11.54, p=.0031 ; V=.23\right]$, with males in the first cluster being less likely than expected to have only visited a casino once in the past year $(f=$ 20, $f_{e}=28.9$, cell $\left.\chi^{2}=2.73\right)$ compared with males in the second cluster $\left(f=46, f_{e}=37.1\right.$, cell $\chi^{2}=$ 
2.13) while males in the first cluster were more likely than expected to have visited a casino seven or more times in the past year $\left(f=32, f_{e}=22.8\right.$, cell $\left.\chi^{2}=3.74\right)$ compared with males in the second cluster $\left(f=20, f_{e}=29.2\right.$, cell $\left.\chi^{2}=2.91\right)$. These results suggested that males who were seeking risk-taking/gambling as a rush and emotional self-classification were more likely to visit a casino than males who were seeking communing and emotional self-classification. A chisquare test conducted on the females in the study group was also significant $\left[\chi^{2}(4, N=205)=\right.$ 10.67, $p=.0306 ; V=.16$ ], with females in the first cluster being less likely than expected to have visited a casino only once in the past year $\left(f=16, f_{e}=20.9\right.$, cell $\left.\chi^{2}=1.15\right)$ and more likely to have visited seven or more times $\left(f=16, f_{e}=9.1\right.$, cell $\left.\chi^{2}=5.18\right)$ while females in the second cluster were more likely than expected to have visited a casino only once in the past year $(f=33$, $f_{e}=27.8$, cell $\left.\chi^{2}=0.98\right)$ and less likely to have done so seven or more times $\left(f=6, f_{e}=12.1\right.$, cell $\left.\chi^{2}=3.08\right)$. These results suggested that females who were seeking emotional self-classification and to escape from everyday problems were more likely to visit a casino than females who were seeking communing and emotional self-classification.

\section{Discussion}

Based on the results of the data analysis, five important casino gambling motivations emerged: risk-taking/gambling as a rush, learning/cognitive self-classification, escaping everyday problems, communing, and emotional self-classification. This finding is not a complete inventory of casino gambling motivations. Rather, these motivations seem a reasonable foundation for the continued development of such a catalogue. Of interest to this study was how these casino gambling motivations varied based on inter- and intra-gender considerations. 


\section{Inter-Gender Variation of Casino Gambling Motivations}

The findings indicated that male and female motivations for casino gambling differed significantly, with risk-taking/gambling as a rush and learning/cognitive self-classification being more important for male casino visitors than for female casino visitors. These results were generally expected since previous research suggested that males were more likely to engage in risk-taking activities (e.g., Bruce \& Johnson, 1994; Hudgens \& Fatkin, 1985), as well as having a greater desire for the feelings of excitement and exhilaration that accompany such acts (Lyng, 1990). Previous research has also suggested that being able to keep a "poker face" was a skill that could be learned (Walker, 1992) and its use allowed casino gamblers the opportunity to maintain or enhance their reputation and standing with others (Abt et al., 1985). In contrast, we had expected that the emotional self-classification motivation would be more important for male casino visitors than for female casino visitors while the escaping everyday problems motivation would be more important for female casino visitors. Although the follow-up ANOVAs did not support these expectations, these results should not be construed as meaning that these motivations were not important in terms of gender. A closer examination of the motivation clusters provided strong support for why it is also important to look at intra-gender differences in leisure research (Henderson, 1996; Henderson et al., 1989; Shaw, 1999).

\section{Intra-Gender Variation of Casino Gambling Motivations}

Even though risk-taking/gambling as a rush and emotional self-classification were important motivations for a large percentage (44\%) of males in the study group, communing and emotional self-classification were important motivations for an even larger percentage (56\%). While the former finding is consistent with previous research the latter finding has not been noted specifically in terms of what motivates many male casino gamblers. Cotte (1997) and 
others (Neigbors et al., 2002; Walker, 1992) identified communing as a motivation for gambling but we can only suppose that the importance of this motivation for males has been overlooked due, perhaps, to greater research interest in other gendered types of gambling motivations (e.g., risk-taking/gambling as rush).

Communing was also an important motivation for a majority (74\%) of females in the study group with one cluster indicating only this motivation as being important while a second cluster indicated that communing along with emotional self-classification were important. Although relatively little research exists regarding communing as a motivation (Neigbors et al., 2002; Sheeran \& Orbell, 1999), the finding that female casino gamblers do place a great deal of importance on social interaction was consistent with Dixley's (1987) work with female bingo players. At least two explanations exist as to why one cluster emphasized emotional selfclassification while the other did not. First, a gambler may be more likely to "just be yourself" when with others with whom you feel comfortable and whom feel comfortable with you (Turner \& Billings, 1991). In some cases this kind of relationship could be disrupted if others saw an emotional display as being either overly angry after a loss (Abt et al., 1985) or overly celebratory after a win (Cotte, 1997). Thus, under some circumstances controlling one's emotions may be one way of facilitating communing and, consequently, maintaining a social environment that allows for greater (but not necessarily complete) self-authenticity. Second, because only two female clusters were found with the validation group and only one cluster indicated communing and emotional self-classification were important, the discovery that a study group cluster of females who emphasized only communing may be a statistical anomaly. However, because a cluster of males in the validation group also emphasized only communing, two other possibilities exist. First, some male and female casino gamblers may facilitate communing by controlling 
their emotions while still feeling relatively free to be themselves. Second, some male and female gamblers may facilitate communing either without being concerned about controlling their emotions, or without feeling the need for self-authenticity, or both.

Emotional self-classification was also found to be an important motivation for females in the study group's third cluster along with the motivation to escape everyday problems. Although the finding that some females want to avoid quotidian concerns by gambling is consistent with previous research literature (Brown \& Coventry, 1997; Hing \& Breen, 2001; Lesieur, 1993), the process of doing so in regard to emotional self-classification has not been discussed previously. Casino gambling may not only allow some women to escape their everyday problems, but it may also through the process of compensatory secondary control help ameliorate the lack of perceived control women have over external events in their day-to-day lives (McConatha \& Huba, 1999). According to Schulz and Heckhausen (1996), compensatory secondary control "serves to buffer the negative effects of failure or losses on the individual's motivation for primary control" (p. 710) through a variety of cognitive, affective, and behavioral strategies. In the case of the female gamblers in this cluster, the strategy they employed was to control their emotional display when they visited casinos. In this regard they seemed quite similar to some of the wilderness visitors in Scherl's (1989) study so the same psychological benefits obtained by wilderness visitors may also be acquired by casino gamblers (e.g., increased self-efficacy and self-confidence). Thus, for the women in this cluster, casino gambling may act not only as an escape mechanism but also as a coping strategy. ${ }^{8}$

For some females casino gambling may act as a site for negotiating traditional feminine gender roles while for some males gambling may act as a site for proving traditional masculine gender roles. Risk-taking/gambling as a rush and emotional self-classification were important 
motivations for males in one cluster in the study group as well as one cluster in the validation group. Based on Beneke's (1997) contention that masculinity must constantly be proven and Lois' (2001) finding that this often occurred by engaging in emotional stoicism (see also Connell, 1987; Kimmel, 1996), some male casino gamblers may be motivated to take risks and to control their emotions in order to validate their masculinity to themselves. In this way, these male casino gamblers may feel free to "just be themselves," albeit a type of self that is consistent with traditional masculine gender roles.

Finally, males who were motivated to commune were less likely to visit casinos than were males who were motivated to seek risk-taking/gambling as a rush and emotional selfclassification. Similarly, females who were motivated to commune were less likely to visit casinos than were females who were motivated to seek emotional self-classification and to escape everyday problems. One reason for this finding may be because, while numerous leisure settings can satisfy people's desire to socialize, casinos may be one of the few places where the other motivations mentioned can also be satisfied. If correct, this suggestion would mean that for some men casinos provide an ideal place to prove their masculinity. For some women casinos provide a place to escape their everyday problems and, through compensatory secondary control, to cope with the social and economic costs and constraints associated with traditional female gender roles. Casinos, therefore, may exemplify a type of gendered leisure setting that appeals to both men and women, albeit for very different reasons.

\section{Conclusion}

The two objectives of this study were to examine if motivations for casino gambling vary by gender and, based on motivations for casino gambling, to ascertain different types of male and female gamblers. In order to accomplish these objectives, a set of scales for measuring 
motivations for casino gambling had to be developed. Arguably, the development of these scales may also have been one of the biggest limitations of this study, as we were not able to create acceptable items for all of the motivations we identified. Additionally, while our discussion of male gamblers' desire for risk-taking/gambling as a rush as well as female gamblers' desire for escape was consistent with previous research, the quantitative nature of our study did not allow us to examine these issues in the depth they merit. Finally, although our cluster solutions were generally supported, some differences between the study and validation groups did exist.

We believe that many of the current study's limitations can be ameliorated by future research. For example, the use of gender within this study as an explanatory variable was useful in that our understanding of gender differences can offer a possible understanding for differences and similarities that exist between- and within-gender groups. However, the results of this study clearly illustrated that while the concept of gender can explain some of the variance within the population of casino gamblers, a great need for further research exists. Our first recommendation is that further work be done on developing a comprehensive, reliable, and valid inventory of casino gambling motivations, not unlike the Recreation Experience Preference (REP) scales developed for outdoor recreation. Second, we recommend future research be undertaken to better understand the importance both male and female casino gamblers place on communing and emotional self-classification. Third, we recommend future research also be undertaken to better understand how other leisure settings act as sites where men can prove their masculinity and women can negotiate the costs and constraints of femininity.

In closing, little doubt exists that casino gambling has become an extremely popular and economically important leisure activity. We hope this study has helped shed some light on why ever-increasing numbers of people are going to casinos as well as the motivations they share and 
do not share. We also hope that by using gender as an explanatory rather than descriptive variable (Henderson, 1990), particularly in terms of "the gendered nature of men's leisure" (Henderson \& Shaw, 2003, p. 1), we have contributed to the existing body of literature on women and men's leisure experiences. 


\section{References}

Abt, V., \& Smith, J. (1982). Playing the game in mainstream American. In F. Manning (Ed.), Worlds of play: The proceedings of the 1981 Association for the Anthropological Study of Play. New York: Leisure Press.

Abt, V., Smith, J., \& McGurrin, M. (1985). Ritual, risk, and reward: A role analysis of race track and casino encounters. Journal of Gambling Behavior, 1, 64-75.

Arnould, E., \& Price, L. (1993). "River magic": Hedonic consumption and the extended service encounter. Journal of Consumer Research 20, 24-45.

Azmier, J. (2000). Canadian gambling behaviour and attitudes: A summary report. Calgary, AB: Canada West Foundation.

Azmier, J. (2001). Gambling in Canada 2001: An overview. Calgary, AB: Canada West Foundation.

Baumeister, R. (1990). Anxiety and deconstruction: On escaping the self. In J. Olson \& M. Zanna (Eds.), Self-inference processes: The Ontario symposium, Volume 6 (pp. 259-291). Hillsdale, NJ: Lawrence Erlbaum.

Baumeister, R. (1991). Escaping the self. Basic Books.

Bem, S.L. (1993). The lenses of gender. New Haven, CN: Yale University Press.

Beneke, T. (1997). Proving manhood. Berkeley, CA: University of California Press.

Brown, S. \& Coventry, L. (1997). Queen of hearts: The needs of women with gambling problems. Melbourne, Australia: Financial and Consumer Rights Council.

Bruce, A., \& Johnson, J. (1994). Male and female betting behavior: New perspectives. Journal of Gambling Studies, 10, 183-198. 
Celsi, R., Rose, R., \& Leigh, T. (1993). An exploration of high-risk leisure consumption through skydiving. Journal of Consumer Research, 20, 1-38.

Chaplin, J. (1985). Dictionary of psychology. New York: Dell.

Cohen, J. (1977). Statistical power analysis for the behavioral sciences (revised ed.). Hillsdale, NJ: Erlbaum.

Cohen, J. (1992). A power primer. Psychological Bulletin, 112, 155-159.

Comrey, A., \& Lee, H. (1992). A first course in factor analysis (2nd ed.). Hillsdale, NJ: Erlbaum.

Connell, R. (1987). Gender and power. Stanford, CA: Stanford University Press.

Cotte, J. (1997). Chances, trances, and lots of slots: Gambling motives and consumption experiences. Journal of Leisure Research, 29, 380-406.

Dixley, R. (1987). It's a great feeling when you win: Women and bingo. Leisure Studies, 6, 199214.

Etaugh, C., \& Bridges, J. (2001). The psychology of women: A lifespan perspective. Needham Heights, PA: Allyn \& Bacon.

Fabrigar, L., Wegener, D., MacCallum, R., \& Strahan, E. (1999). Evaluating the use of exploratory factor analysis in psychological research. Psychological Methods, 4, 272299.

Freysinger, V., \& Flannery, D. (1992). Women's leisure: Affiliation, self-determination, empowerment and resistance? Loisir et Societe/Society and Leisure, 15, 303-321.

Geertz, C. (1973). The interpretation of cultures. New York: Basic Books.

Getty, H., Watson, J., \& Frisch, G. (2000). A comparison of depression and styles of coping in male and female GA members and controls. Journal of Gambling Studies, 16, 377-391. 
Goffman, E. (1961). Encounters: Two studies in the sociology of interaction. Indianapolis, IN: Bobbs-Merrill.

Hair, J., \& Black, W. (2000). Cluster analysis. In L. Grimm \& P. Yarnold (Eds.), Reading and understanding more multivariate statistics (pp. 147-205). Washington, DC: American Psychological Association.

Henderson, K. (1990). The meaning of leisure for women: An integrative review of the research. Journal of Leisure Research, 22, 228-243.

Henderson, K. (1996). One size doesn't fit all: The meanings of women's leisure. Journal of Leisure Research, 28, 139-154.

Henderson, K., Bialeschki, M., Shaw, S., \& Freysinger, V. (1989). A leisure of one's own: A feminist perspective on women's leisure. State College, PA: Venture.

Henderson, K., \& Shaw, S. (2003). Leisure research about gender and men: The weaker link? In S. Stewart \& W. Borrie (Compilers), Abstracts from the 2003 Leisure Research Symposium (pp. 1). Ashburn, VA: National Recreation and Park Assocation.

Hing, N., \& Breen, H. (2001). Profiling lady luck: An empirical study of gambling and problem gambling amongst female club members. Journal of Gambling Studies, 17, 47-69.

Holt, D. (1995). How consumers consume - A typology of consumption practices. Journal of Consumer Research, 22, 1-16.

Hudgens, G., \& Fatkin, L. (1985). Sex differences in risk taking: Repeated sessions on a computer-simulated task. Journal of Psychology, 119, 197-206.

Huizinga, J. (1955). Homo Ludens: A study of the play element in culture. Boston: Beacon Hill. Kimmel, M. (1996). Manhood in America: A cultural history. New York: Free Press. 
Kraus, R. (2001). Recreation and leisure in modern society $\left(6^{\text {th }}\right.$ ed.). Sudbury, MA: Jones and Bartlett Publishers.

Lesieur, H. (1993). Female pathological gamblers and crime. Gambling behavior and problem gambling, in W. Eadington \& J. Cornelius (Eds.), Reno, NV: Institute for the Study of Gambling and Commercial Gaming, University of Nevada.

Lois, J. (2001). Peaks and valleys: The gendered emotional culture of edgework. Gender \& Society, 15 , 381-406.

Lyng, S. (1990). Edgework: A social psychological analysis of voluntary risk taking. American Journal of Sociology, 95, 851-886.

Mackie, M. (1991). Gender relations in Canada: Further explorations. Toronto, ON: Harcourt Brace Canada.

Manfredo, M., Driver, B., \& Tarrant, M. (1996). Measuring leisure motivation: A meta-analysis of the recreation experience preference scales. Journal of Leisure Research, 28, 188-213.

Mannell, R., \& Kleiber, D. (1997). The social psychology of leisure. State College, PA: Venture. Marin, P. (1995). The prejudice against men. In E.D. Nelson \& B.W. Robinson (Eds.), Gender in the 1990s: Images, realities, and issues (pp. 490-498). Toronto, ON: Nelson Canada.

McConatha, J. \& Huba, H. (1999). Primary, secondary, and emotional control across adulthood. Current Psychology: Developmental Learning Personality Social, 18, 164-170.

Milligan, G., \& Cooper, M. (1985). An examination of procedures for determining the number of clusters in a data set. Psychometrika, 50, 159-179.

Neighbors, C., Lostutter, T., Cronce, J., \& Larimer, M. (2002). Exploring college student gambling motivation. Journal of Gambling Studies, 18, 361-370. 
Oderkirk, J. \& Lochhead, C. (1995). Lone parenthood: Gender differences. In E.D. Nelson \& B.W. Robinson (Eds.), Gender in the 1990s: Images, realities, and issues (pp. 397-404). Toronto, ON: Nelson Canada.

Potenza, M., Steinberg, M., McLaughlin, S., Wu, R., Rounsaville, B., \& O'Malley, S. (2001). Gender-related differences in the characteristics of problem gamblers using a gambling helpline. American Journal of Psychiatry, 158, 1500-1505.

Profile of the American Casino Gambler: Harrah's Survey 2002. (2002). Retrieved September 25, 2003 from http://www/harrahs.com/about_us/survey/survey_02.5pdf.

Scherl, L. (1989). Self in wilderness: Understanding the psychological benefits of individualwilderness interaction through self-control. Leisure Sciences, 11, 123-135.

Schulz, R., \& Heckhausen, J. (1996). A lifespan model of successful aging. American Psychologist, 51, 702-714,

Shaw, S. (1999). Gender and leisure. In E. Jackson \& T. Burton (Eds.), Leisure Studies: Prospects for the Twenty-First Century (pp. 271-281). State College, PA: Venture.

Shaw, S. (2001). Conceptualizing resistance: Women's leisure as political practice. Journal of Leisure Research, 33, 186-201.

Sheeran, P., \& Orbell, S. (1999). Augmenting the theory of planned behavior: Roles for anticipated regret and descriptive norms. Journal of Applied Social Psychology, 29, 21072142.

Sherry, J. (1990). A sociocultural analysis of a midwestern American flea market. Journal of Consumer Research, 17, 13-30.

Statistics Canada (2003). 2001 Census Highlight Tables. Retrieved November 2, 2003 from http://www12.statcan.ca/english/census01/products/highlight/index.cfm. 
Tabachnick, B., \& Fidell, L. (1996). Using multivariate statistics (3 ${ }^{\text {rd }}$ ed.). New York: HarperCollins.

Trevorrow, K., \& Moore, S. (1999). The association between loneliness, social isolation and women's electronic gaming machine gambling. Journal of Gambling Studies, 14, 263284.

Turner, R., \& Billings, V. (1991). The social context of self-feeling. In J. Howard \& P. Callero (Eds.), The self-society dynamic: Cognition, emotion, and action (pp.103-122). Cambridge: Cambridge University Press.

Volberg, R. (2003). Intro: Guest editorial. EGambling: The electronic journal of gambling issues, 8. Retrieved September 21, 2003 from http://www.camh.net/egambling/issue8/intro.html.

Walker, M. (1992). The psychology of gambling. Tarrytown, NY: Pergamon.

Weighill, A. J. (2001). Exploring the experiences of women involved in the 2000 Habitat for Humanity Women Build. Unpublished master's thesis, University of Waterloo, Waterloo, Ontario, Canada.

Weinfurt, K. P. (1995). Multivariate analysis of variance. In L. Grimm \& P. Yarnold (Eds.), Reading and understanding multivariate statistics (pp. 245-276). Washington, DC: American Psychological Association.

Welte, J., Barnes, G., Wieczorek, W., Tidwell, M., \& Parker, J. (2002). Gambling participation in the U.S.: Results from a national survey. Journal of Gambling Studies, 18, 313-337.

Wiebe, J., Single, E., \& Falkowski-Ham, A. (2001). Measuring gambling and problem gambling in Ontario. Retrieved September 25, 2003 from http://www.gamblingresearch.org/downloads/documents/pdf/cpgi.pdf. 
Williams, D., Patterson, M., Roggenbuck, J., \& Watson, A. (1992). Beyond the commodity metaphor: Examining emotional and symbolic attachment to place. Leisure Sciences, 14, 29-46.

Zuckerman, M. (1979). Sensation seeking: Beyond the optimal level of arousal. Hillsdale, NJ: Erlbaum. 


\section{Footnotes}

${ }^{1}$ For example, a search of Leisure Sciences (using the PsycINFO database and the keyword "gambling") did not uncover any papers published on this topic between 1985 and September 2003.

${ }^{2}$ The decision to conduct the study in two Western Canadian metropolitan areas was based on: (a) the growth of gambling and casino gambling in Canada, (b) the location of the study researchers, and (c) the provision of research funding by a provincial agency.

${ }^{3}$ Although an attempt was made to develop and test items that would measure Cotte's (1997) self-definition motivation, it was unsuccessful due in part to the number of different roles casino gamblers can select from (e.g., rebels, casino pros, variety seekers).

${ }^{4}$ For comparative purposes, the median age in the province where the study was conducted is 34 years for males versus 36 years for females, with $15 \%$ of males and $22 \%$ of females have completed community college or the equivalent, and $21 \%$ of males and $22 \%$ of females having attained a Bachelors degree or greater (Statistics Canada, 2003).

${ }^{5}$ For comparative purposes, in Ontario Wiebe, Single, and Falkowski-Ham (2001) found that people who gambled at in-province casino tables did so approximately 6.3 times per year while those who gambled at out-of-province casinos did so approximately 1.7 times per year. In contrast, Welte et al. (2002) found that U.S. casino gamblers averaged 11 visits per year, although this figure is nearly twice the average (5.7 visits) reported in another study (Profile of the American Casino Gambler: Harrah's Survey 2002) of American casino visitors.

${ }^{6}$ Because participants were selected based on gender as well as--in the case of 400 individuals--having visited a distant casino (i.e., greater than 80 kilometres), a MANOVA was first conducted on the five casino gambling motivation scales using gender, type of visits (i.e., 
only local casinos, only distant casinos, both), and their interaction. Because the interaction was not significant [Wilk's $\Lambda=0.99, F(10,1734)=1.19, p>.2902$ ], only the effect of gender was subsequently examined.

${ }^{7}$ The cluster order is not important as the first cluster seed is simply a function of which observation is read first by the SAS FASTCLUS program (Hair \& Black, 2000).

${ }^{8}$ The effectiveness of casino gambling as a long-term coping strategy remains open to debate however. A study by Potenza et al. (2001, p. 1504) has raised the possibility that women, once they begin gambling, may develop gambling problems at a more rapid rate than men. 
Table 1

Cotte's (1997) Casino Gambling Motivations

Dimensions

\begin{tabular}{llll} 
Motive & Focus of Action & Purpose of Action & Nature of Experience \\
\hline Learning/evaluating & Activity & Autotelic & Rational/Utilitarian \\
Gambling as a rush & Activity & Autotelic & Emotional/Hedonic \\
Self-definition & Activity & Instrumental & Rational/Utilitarian \\
Risk-taking & Activity & Instrumental & Emotional/Hedonic \\
Cognitive S-C & Interpersonal & Instrumental & Rational/Utilitarian \\
Emotional S-C & Interpersonal & Instrumental & Emotional/Hedonic \\
Competing & Interpersonal & Autotelic & Rational/Utilitarian \\
Communing & Interpersonal & Autotelic & Emotional/Hedonic \\
\hline
\end{tabular}

Note: S-C stands for self-classification. 
Table 2

Factor Analysis of Casino Gambling Motivation Items

Factor

Item

Risk/ Learn/ Escape Commune Emotional Rush Cog. S-C Problems S-C

To take risks

To take chances

To have thrills .75

To feel exhilarated .62

To be seen by others as a smart gambler .81

To be seen by other gamblers as a skilled player .80

To develop your skills and abilities .70

To keep a "poker face" when you're gambling .59

To avoid everyday problems for awhile .90

To get away from the usual demands of life .90

To do things with your companions .91

To be with members of your group .88

To just be yourself

To be in control whether you win or lose .69

Note: Cog. S-C stands for cognitive self-classification. Only items having loadings $\geq|.55|$ on one factor and having loadings $\leq|.32|$ on the other factors are shown. 
Table 3

Analysis of Variance on Casino Gambling Motivation Scales by Gender

\begin{tabular}{|c|c|c|c|c|c|}
\hline \multirow[b]{2}{*}{ Scale } & Male & Female & \multirow[b]{2}{*}{$d f$} & \multirow[b]{2}{*}{$F$} & \multirow[b]{2}{*}{$d$} \\
\hline & $M \quad(S D)$ & $M \quad(S D)$ & & & \\
\hline Risk-taking/rush & $2.31(0.82)$ & $1.87(0.75)$ & 1,875 & $70.19 *$ & .51 \\
\hline Learn/cognitive S-C & $1.36(0.53)$ & $1.15(0.37)$ & 1,875 & $46.45 *$ & .31 \\
\hline Escaping problems & $1.76(0.93)$ & $1.71(0.90)$ & 1,875 & 0.67 & --- \\
\hline Communing & $2.83(1.00)$ & $2.74(1.00)$ & 1,875 & 2.03 & --- \\
\hline Emotional S-C & $2.47(0.92)$ & $2.45(1.01)$ & 1,875 & 0.14 & --- \\
\hline
\end{tabular}

Note: Importance measured using a four-point scale where: 1 = not important, 2 = slightly important, 3 = very important, 4 = extremely important.

${ }^{*} p<.0001$. 
Table 4

Cluster Analysis of Casino Gambling Motivation Scales by Gender - Study Group

\begin{tabular}{|c|c|c|c|c|c|}
\hline \multirow[b]{3}{*}{ Scale } & \multicolumn{2}{|c|}{ Male } & \multicolumn{3}{|c|}{ Female } \\
\hline & Cluster 1 & Cluster 2 & Cluster 1 & Cluster 2 & Cluster 3 \\
\hline & Mean (SD) & Mean (SD) & Mean (SD) & Mean (SD) & Mean (SD) \\
\hline Risk-taking/rush & $0.41^{\mathrm{a}}(0.56)$ & $-0.10(0.40)$ & $0.05(0.59)$ & $-0.46^{\mathrm{a}}(0.55)$ & $-0.03(0.42)$ \\
\hline Learn/cognitive S-C & $-0.57^{\mathrm{a}}(0.52)$ & $-0.91^{\mathrm{a}}(0.56)$ & $-1.05^{\mathrm{a}}(0.60)$ & $-1.02^{\mathrm{a}}(0.34)$ & $-0.58^{\mathrm{a}}(0.41)$ \\
\hline Escaping problems & $0.06(0.63)$ & $-0.71^{\mathrm{a}}(0.67)$ & $0.30^{\mathrm{a}}(0.59)$ & $-0.88^{\mathrm{a}}(0.47)$ & $-0.15^{\mathrm{a}}(0.43)$ \\
\hline Communing & $-0.10 \quad(0.57)$ & $1.30^{\mathrm{a}}(0.52)$ & $-0.04(0.62)$ & $1.29^{\mathrm{a}}(0.50)$ & $0.88^{\mathrm{a}}(0.58)$ \\
\hline Emotional S-C & $0.20^{\mathrm{a}}(0.66)$ & $0.42^{\mathrm{a}}(0.59)$ & $0.75^{\mathrm{a}}(0.57)$ & $1.07^{\mathrm{a}}(0.51)$ & $-0.12^{a}(0.36)$ \\
\hline Participants (\%) & 95 (44\%) & 122 (56\%) & 55 (27\%) & 73 (36\%) & 77 (38\%) \\
\hline
\end{tabular}

Note: Scales have been standardized within-case. Motivations that have a mean with a superscript are significantly $(p<.01)$ different than 0.00 for that cluster. 
Table 5

Cluster Analysis of Casino Gambling Motivation Scales by Gender - Validation Group

\begin{tabular}{|c|c|c|c|c|c|}
\hline \multirow[b]{3}{*}{ Scale } & \multicolumn{3}{|c|}{ Male } & \multicolumn{2}{|c|}{ Female } \\
\hline & Cluster 1 & Cluster 2 & Cluster 3 & Cluster 1 & Cluster 2 \\
\hline & Mean (SD) & Mean (SD) & Mean (SD) & Mean (SD) & Mean (SD) \\
\hline Risk-taking/rush & $0.08(0.55)$ & $0.11(0.54)$ & $0.47^{\mathrm{a}}(0.53)$ & $0.10(0.45)$ & $-0.22^{\mathrm{a}}(0.57)$ \\
\hline Learn/cognitive S-C & $-0.88^{\mathrm{a}}(0.43)$ & $-0.84^{\mathrm{a}}(0.50)$ & $-0.71^{\mathrm{a}}(0.54)$ & $-0.63^{\mathrm{a}}(0.55)$ & $-0.98^{\mathrm{a}}(0.37)$ \\
\hline Escaping problems & $-0.39^{\mathrm{a}}(0.54)$ & $-1.01^{\mathrm{a}}(0.39)$ & $0.25^{\mathrm{a}}(0.64)$ & $0.21^{\mathrm{a}}(0.70)$ & $-0.66^{\mathrm{a}}(0.49)$ \\
\hline Communing & $1.29^{\mathrm{a}}(0.42)$ & $0.66^{\mathrm{a}}(0.69)$ & $-0.09(0.53)$ & $0.05(0.61)$ & $1.33^{\mathrm{a}}(0.49)$ \\
\hline Emotional S-C & $-0.11(0.46)$ & $1.09^{\mathrm{a}}(0.42)$ & $0.09 \quad(0.47)$ & $0.27^{\mathrm{a}}(0.72)$ & $0.54^{\mathrm{a}}(0.73)$ \\
\hline Participants (\%) & 84 (39\%) & 69 (32\%) & 64 (29\%) & $112(46 \%)$ & 129 (54\%) \\
\hline
\end{tabular}

Note: Scales have been standardized within-case. Motivations that have a mean with a superscript are significantly $(p<.01)$ different than 0.00 for that cluster. 